\title{
The Effect Of Pad, Dau And Dak On Poverty Rates In Java
}

\author{
Suryani Yuli Astuti ${ }^{*}$, Muhammad Ali Basyah², Farokhah Muzayinatun Niswah ${ }^{3}$ \\ ${ }^{1,2,3}$ Faculty of Economics and Business, Universitas Muhammadiyah Lamongan, \\ Lamongan, 62218, Indonesia \\ ${ }^{*}$ Corresponding author: \\ Email: 9suryani1976.ya@gmail.com
}

\begin{abstract}
.
This study was made to determine the extent of the influence of Regional Original Income (PAD), General Allocation Funds (DAU) and Special Allocation Funds (DAK) on poverty through Regional Expenditures in Bitung City. Based on the time series data for 2016-2018 and processed based on the multiple regression analysis method for testing the path analysis used, it can be seen that the relationship between PAD, DAU, DAK and poverty rates on the island of Java. The results showed that the province of West Java on PAD, DAU and DAK had a partial effect on poverty rates and PAD, DAU and DAK had a simultaneous effect on poverty rates. Central Java Province on PAD has a negative effect on poverty rates, DAU and DAK have a partial effect on poverty rates and PAD, DAU and DAK have a simultaneous effect on poverty rates. DIY Province, although PAD has a negative effect on poverty rates, DAU has an effect on poverty and DAK has no partial effect on poverty rates and PAD, DAU and DAK have a simultaneous effect on poverty rates. East Java Province, Partially PAD has no effect on poverty rates, DAU has no effect on poverty rates and DAK has no effect on poverty rates and the influence of $P A D, D A U$ and DAK simultaneously affects poverty rates.
\end{abstract}

Keywords: Poverty, Local Revenue, General Allocation Fund, Special Allocation Fund

\section{INTRODUCTION}

National development is one of the efforts to improve the welfare of all aspects of the nation's life, including full human development as well as the development of infrastructure or existing resources in Indonesia. Economic growth and development are two concepts that cannot be separated. In terms of the economy in Indonesia, the process of development and economic growth has various challenges, including poverty. Sustainable problems that are closely related to economic development, namely poverty and economic growth are an illustration of the development process. Development is a multi-dimensional process that involves major changes in social structures, accustomed mental attitudes and national institutions, including patterns of acceleration or acceleration of economic growth and absolute poverty eradication.

Poverty is the enemy of the main goal of regional autonomy. Where, the granting of broad autonomy to local governments is intended to accelerate the realization of community welfare through service improvement, empowerment and community participation. This has brought consequences for local governments in regulating and managing their own regional interests according to their own initiatives, based on 
community aspirations and of course in accordance with applicable laws and regulations. Decentralization is the right, need, and power of the region to control, implement and implement only the laws and regulations.

No. 32 of 2004. Decentralization or regional autonomy requires regional administrators and the community to be mutually sustainable in the development of their respective regions (Arini., Mustika \& Setyadhi, 2015). Mardiasmo (2002) states that decentralization causes each region to be expected to be able to find sources of income for development needs without expecting too much from the desire to depend on assistance from the central government balancing funds. The purpose of regional autonomy or decentralization is to avoid the dependence of the regions on the central government, especially in fiscal management. Avoiding depending on the central government can be done, one of which is by managing the Regional Original Revenue (PAD) as much as possible (Mahmudi., 2015).Carrying out regional autonomy, local governments are required to run an effective, efficient, and able to support the role of the community in improving equity and justice by developing all the potentials possessed by each region so that in the end poverty can be eradicated and bring prosperity to the community. The principles of regional autonomy must be met by local governments, namely democratization, transparency, public accountability and community participation. This means that local governments are given broad, real, responsible and proportional authority in regulating, sharing and utilizing national resources and balancing central and regional finances. The enactment of Law number 23 of 2014 concerning regional government with the essence of the regional autonomy policy that is currently rolling is a manifestation of the authority in the area of regional finance. The regional autonomy policy is intended to bring the government closer to the community so that the services provided are getting better. According to Suparmoko (2002), by bringing the government closer to the community, it is hoped that public services can be realized better according to the needs of the community.

Development in the economic sector is the most essential thing in developing potential and developing the region. According to Law no. 23 of 2014 concerning regional government for the implementation of regional government authority, the central government will transfer balancing funds to regional governments. The balancing fund consists of the General Allocation Fund (DAU), the Special Allocation Fund (DAK) and the Central Tax Revenue Sharing (BHPP). Meanwhile, local governments have their own sources of funding in the form of Regional Original Income (PAD), Regional Loans, and Other Legitimate Regional Revenues, all of which are included in the Regional Revenue component. According to Suparmoko (2010), regional financial sources consist of: PAD, balancing funds (Dana Sharing, DAU, DAK) directly managed by local governments through the Regional Revenue and Expenditure Budget, while other sources of funds are managed by the central government in collaboration with local governments. The policy on the use of funds is left to the local government (Prakarsa \& Noor, 2014). In the implementation of 
decentralization, the role of transfer funds cannot be avoided, considering that the delegated autonomy requires the regions to be able to complete various government affairs which are the regional authority in terms of financing. To carry out real and responsible regional autonomy, local governments are required to be able to explore their own financial sources in order to finance government, development and community administrators who are under their authority.

This indicates that the region must strive to be able to increase Regional Original Income (PAD), both increasing the receipt of existing PAD sources and extracting new PAD sources in accordance with existing provisions and taking into account the economic conditions and potential of the community, because PAD is a benchmark. for regions in implementing and realizing regional autonomy.In principle, the greater the contribution of PAD to the Regional Revenue and Expenditure Budget (APBD) will indicate the smaller the dependence of the region on the center. In general, the Regional Revenue and Expenditure Budget (APBD) of a region is dominated by government contributions and other contributions, which are regulated by laws and regulations. This causes the regions to be very dependent on the central government, (Suparmoko, 2010). Regional Expenditures are the main part of the APBD related to the government's role in improving people's welfare. The Regency City Government in carrying out its development requires funding, which in regional financial management is called Revenue. In financing the implementation of regional development in the Regency/City of Java Island, regional income plays an important role, because with sufficient income, the planned development will run well. In connection with the regional autonomy policy, the important thing that must be considered is the availability of funds (regional income) to finance the increasing tasks and obligations. The high local revenue (PAD) is a determinant of the success of regional autonomy, in addition to the quality of local government officials and the high level of public education. Regional autonomy is to reduce the dependence of local governments on the central government, especially in financial matters, so that regions are expected to be able to finance their finances independently. One of the concerns of local governments is in the management of revenues originating from their own regions (Davey, 1988).

The focus of regional autonomy consists of 3 (three), namely first: autonomy which focuses on the administrative authority of local governments, such as the management of employees, regional expenditures and revenues; second: autonomy focused on the allocation of regional power accompanied by central government control and participation of local people; Third, the emphasis is on the implementation of local government functions that are operated through regional authority in managing the affairs assigned to them (Sanit, 2011). Law No. 32 of 2004 has a definition of PAD including revenue obtained from the region taken from regulations owned by the region uniform with applicable laws. According to Mahmudi (2015), the higher the ability of the region to obtain and explore its own regional income, the higher the 
regional expenditure to increase its original regional income which is in line with the wishes, needs and development.Based on Law no. 33 of 2004 explains that the DAU is a fund that is obtained through domestic receipts given from the center to the regional government in the hope of inter-regional financial justice that is used to finance expenditure needs to carry out decentralization. The financial capacity of each region is different in carrying out activities, especially fiscal decentralization, with this problem the central government makes transfer policies from the center to the regions. Halim (2010) explained that the allocation of APBN funds was given in the hope of equal distribution of regional finances to meet regional funding related to the implementation of fiscal decentralization or regional autonomy, namely the General Allocation Fund. One of the important objectives of the allocation of General Allocation funds is to meet the needs of local governments in terms of providing better public services. (Halim, 2014) Based on Law no. 33 of 2004 explains that DAK is financial assistance originating from the central government which is specifically given in certain regions which is used to finance specific regional needs which are uniform needs with national programs.

The purpose of the Special Allocation Fund is to finance basic needs which are basically national program activities in the fields of education, health, environment, public works, clean water, fisheries, government, sanitation, marine, agriculture, forestry, family planning, trade, and infrastructure. village. (Halim, 2014). According to Sukarna (2013) the determination of the amount of Special Allocation Fund assistance intended for each region is given in accordance with calculations based on special criteria, general criteria and technical criteria. Poverty is one of several main problems that hinder the economic development of a region. Poverty in general can be interpreted as a condition of individual residents or families who are unable to meet their basic needs properly. However, several institutions or parties have set a reference in determining the criteria for the poor. The occurrence of population poverty is broadly caused by external and internal factors of the population.Poverty seen from its causes can be divided into two, namely: absolute poverty and structural poverty. Absolute poverty is poverty caused by internal factors of the population itself. For example, due to low levels of education, low skills, culture and so on. Structural poverty is poverty caused by external factors so that the ability to access economic resources is low, in turn the income of the population becomes low. According to Kuncoro (2004), the measurement of poverty line criteria in Indonesia is measured for absolute poverty. The government institution that usually sets the poverty line criteria is the Central Statistics Agency (BPS). According to BPS (1994), the criteria for the limit of poverty use the size of the rupiah spent per capita per month to meet the minimum food and non-food needs of life. This means that the poverty line criteria are measured from two components, namely the food poverty line and the non-food poverty line. Poverty is a reflection of a person's inability to meet their needs in accordance with applicable standards. 
Table 1. Data on the Number of Poor Populations in Java in Year 2011 - 2015

\begin{tabular}{|l|c|c|c|c|c|}
\hline Provincial Poverty & $\mathbf{2 0 1 1}$ & $\mathbf{2 0 1 2}$ & $\mathbf{2 0 1 3}$ & $\mathbf{2 0 1 4}$ & $\mathbf{2 0 1 5}$ \\
\hline Jawa Barat & $4.650,9$ & $4.430,2$ & $4.375,2$ & 4.239 & $4.435,7$ \\
\hline Jawa Tengah & 5.256 & $4.863,5$ & $4.811,3$ & $4.561,82$ & 4.577 \\
\hline DIY & 29.89 & 28,59 & 28,55 & 27,73 & 28,51 \\
\hline JawaTimur & 5251.45 & $4.992,70$ & 4893,01 & 4788,40 & 4775,92 \\
\hline
\end{tabular}

Source: bps

A good spending allocation is certainly expected to improve the welfare of the people, which can be seen from the indicators of economic growth and the reduction of poverty. The poverty rate is usually also influenced by government spending. Inappropriate and sub-optimal spending allocations can lead to an increase in the poverty rate. Researchers will explore the influence of DAU, DAK and PAD on poverty in Java.

\section{LITERATURE REVIEW}

\section{Regional Original Income (PAD).}

Mardiasmo (2002), Regional Original Revenue is the revenue obtained from the regional tax sector, regional levies, the results of regionally owned companies, the results of separated regional wealth management, and other legitimate regional original revenues. Meanwhile, according to Halim (2014), Regional Original Revenue (PAD) is "all regional revenues originating from regional original economic sources". According to Halim and Nasir (2006), Regional Original Revenue is income earned by the region and collected based on the applicable laws and regulations. The definition of Regional Original Revenue (PAD) according to Permendagri Number 13 of 2006 PAD is separated into four types of income, namely: regional taxes, regional levies, results of regionally owned companies, and results of separated regional management, and other legitimate regional original revenues. The role of Regional Original Revenue (PAD) as a source of financing for regional development is still low. Although the acquisition of Regional Original Income (PAD) is relatively increasing every year, it is still unable to boost the regional economic growth rate of the

\section{General Allocation Fund (DAU).}

The General Allocation Fund (DAU) is one of the transfers of Government funds to local governments sourced from APBN revenues, which are allocated with the aim of equitable distribution of financial power among regions in the context of implementing decentralization. The General Allocation Fund (DAU) is a Block Grant, which means that its use is handed over to the regions according to the priorities and needs of the regions to improve services to the community in the context of implementing regional autonomy. Legal Basis of Law no. 33 of 2004 concerning the Financial Balance between the Central Government and Regional Governments; and PP No. 55 of 2005 concerning the Balancing Fund. The allocation of DAU is allocated to provinces and regencies and cities, the amount of DAU is set at least $26 \%$ of the Net 
Domestic Revenue (PDN) set out in the APBN, and the proportion of DAU for provincial areas and for regencies/cities is determined in accordance with the balance of authority. between provinces and districts/cities.

\section{Special Allocation Fund (DAK).}

Special Allocation Funds (DAK) are funds sourced from APBN revenues allocated to certain regions with the aim of helping to fund special activities which are regional affairs and in accordance with national priorities. Programs that become national priorities are contained in the Government Work Plan for the relevant fiscal year. Then, the technical minister proposes special activities to be funded from the DAK and determined after coordinating with the Minister of Home Affairs, the Minister of Finance, and the State Minister of National Development Planning, in accordance with the Government's Work Plan. The technical minister submits stipulations on special activities to the Minister of Finance.

\section{METHODS}

The data used in this study is secondary data with the type of time series data. The data is in the form of historical data on the poverty rate of the city district government in the Province of Java Island in 2016-2018. Report on the Realization of the Regional Revenue and Expenditure Budget of the regency city government in the Province of Java Island for 2016-2018 in the form of revenue realization consisting of Regional Original Revenue (PAD), Transfer Funds, Other legitimate income and realization of Regional Expenditure (BD) which sourced from the Central Statistics Agency (BPS) and the Ministry of Finance (Kemenkes, 2020).Data Processing Methods This research was conducted using descriptive and quantitative analysis. Descriptive analysis is based on literature studies through articles, books and research results related to Poverty, Regional Revenue and Expenditure Budget (APBD). Meanwhile, in quantitative analysis, it is used to reflect the results and discussions expressed in numbers. Scope of Research In analyzing the effect of Regional Original Income, General Allocation Funds (DAU) and Special Allocation Funds (DAK) on Poverty, the scope of research is determined by using independent variables, including PAD, DAU, DAK and the dependent variable is Poverty.

\section{RESULT AND DISCUSSION Result}

Table 2. Results of PAD, DAU and DAK Poverty Analysis in West Java

\begin{tabular}{|c|c|c|c|c|c|c|c|}
\hline \multirow[b]{2}{*}{ Model } & \multicolumn{2}{|c|}{$\begin{array}{c}\text { Unstandardized } \\
\text { Coefficients }\end{array}$} & \multirow{2}{*}{$\begin{array}{c}\text { Standardized } \\
\text { Coefficients } \\
\text { Beta }\end{array}$} & \multirow[b]{2}{*}{$\mathrm{t}$} & \multirow[b]{2}{*}{ Sig. } & \multicolumn{2}{|c|}{$\begin{array}{l}\text { Collinearity } \\
\text { Statistics }\end{array}$} \\
\hline & B & $\begin{array}{l}\text { Std. } \\
\text { Error }\end{array}$ & & & & Tolerance & VIF \\
\hline 1 (Constant) & $-63,786$ & 16,827 & & $-3,791$ &, 000 & & \\
\hline PAD & $2,422 \mathrm{E}-11$ & , 000 &, 172 & 2,545 & ,013 & ,784 & 1,276 \\
\hline
\end{tabular}




\begin{tabular}{l|l|l|l|l|l|l|l|}
\hline DAU & $8,568 \mathrm{E}-11$ &, 000 &, 374 & 3,970 &, 000 &, 402 & 2,486 \\
DAK & $2,799 \mathrm{E}-10$ &, 000 &, 472 & 5,468 &, 000 &, 477 & 2,095 \\
\hline
\end{tabular}

a. Dependent Variable: Poverty-rate

Based on Table 2 using a 95\% confidence interval or $=0.05$ The results of partial hypothesis testing show that the PAD variable has a tcount value $(2.545)>$ ttable value (1.99), then the decision is to accept $\mathrm{Ha}$ and $\mathrm{H} 0$ rejected. This means that the PAD variable has a significant effect on the poverty rate in the province of West Java. The results of partial hypothesis testing indicate that the DAU variable has a tcount value (3.970) > ttable value (1.99), then the decision is to accept Ha and H0 is rejected. This means that the DAU variable has a significant effect on the poverty rate in the province of West Java. Furthermore, the results of partial hypothesis testing indicate that the DAK variable has a tcount value (5.468) $>$ ttable value (1.99), then the decision is to accept $\mathrm{Ha}$ and $\mathrm{H} 0$ is rejected. This means that the DAU variable has a significant effect on the poverty rate in the province of West Java. If the Fcount $>$ Ftable value, then $\mathrm{H} 0$ is rejected and $\mathrm{Ha}$ is accepted. On the other hand, if the value of Fcount $<$ the value of Ftable, then $\mathrm{HO}$ is accepted and $\mathrm{Ha}$ is rejected

Table 3. Results of PAD, DAU, DAK poverty in West Java

\begin{tabular}{|ll|r|r|r|r|c|}
\hline Model & & Sum of Squares & df & Mean Square & F & Sig. \\
\hline 1 & Regression & 599830,717 & 3 & 199943,572 & 67,897 &, $000^{\mathrm{a}}$ \\
& Residual & 226750,914 & 77 & 2944,817 & & \\
& Total & 826581,631 & 80 & & & \\
\hline
\end{tabular}

a. Predictors: (Constant), DAK, PAD, DAU

b. Dependent Variable: Poverty_rate

The calculation results obtained by the Fcount value of 67.897 . By using the $95 \%$ confidence interval or $=0.05$, the $\mathrm{F}$ distribution table obtained a value of 2.72 . By comparing the value of Fcount with Ftable, then Fcount (67.897) > Ftable (2.72). The decision is that $\mathrm{HO}$ is rejected and $\mathrm{Ha}$ is accepted, meaning that simultaneously the PAD, DAU, and DAK variables have a significant effect on the poverty rate in the province of West Java.

Table 4. Results of PAD, DAU and DAK of Central Java Province

\section{Coefficients $^{\mathrm{a}}$}

\begin{tabular}{|c|c|c|c|c|c|c|c|}
\hline \multirow[b]{2}{*}{ Model } & \multicolumn{2}{|c|}{$\begin{array}{l}\text { Unstandardized } \\
\text { Coefficients }\end{array}$} & \multirow{2}{*}{$\begin{array}{c}\text { Standardized } \\
\text { Coefficients } \\
\text { Beta }\end{array}$} & \multirow[b]{2}{*}{$\mathrm{t}$} & \multirow[b]{2}{*}{ Sig. } & \multicolumn{2}{|c|}{$\begin{array}{l}\text { Collinearity } \\
\text { Statistics }\end{array}$} \\
\hline & B & $\begin{array}{l}\text { Std. } \\
\text { Error }\end{array}$ & & & & Tolerance & VIF \\
\hline 1 (Constant) & $-65,514$ & 15,733 & & $-4,164$ & ,000 & & \\
\hline PAD & $-4,722 \mathrm{E}-11$ &, 000 &,- 168 & $-2,298$ & ,024 & ,691 & 1,447 \\
\hline DAU & $1,771 \mathrm{E}-10$ &, 000 & 677 & 6,704 & ,000 & ,361 & 2,772 \\
\hline DAK & $1,350 \mathrm{E}-10$ &, 000 & ,201 & 2,157 & ,033 & ,424 & 2,360 \\
\hline
\end{tabular}

a. Dependent Variable: Poverty_rate 
Based on Table 4 using the $95 \%$ confidence interval or $=0.05$ The results of partial hypothesis testing show that the PAD variable has a tcount value $(2.298)>$ ttable value (1.99), then the decision is to accept $\mathrm{Ha}$ and $\mathrm{H} 0$ rejected. This means that the PAD variable has a negative effect on the poverty rate in the province of Central Java. Second The results of partial hypothesis testing indicate that the DAU variable has a tcount value (6.704) $>$ ttable value (1.99), then the decision is to accept Ha and $\mathrm{H} 0$ is rejected. This means that the DAU variable has a significant effect on poverty rates in the province of Central Java, and the third partial hypothesis testing results show that the DAK variable has a tcount value $(2.157)>$ ttable value (1.99), then the decision is to accept $\mathrm{Ha}$ and $\mathrm{H} 0$ is rejected. This means that the DAU variable has a significant effect on the poverty rate in the province of Central Java.To test the effect of PAD, DAU, and DAK simultaneously on poverty rates in the province of Central Java, the F statistic test ( $F$ test) was used. If the Fcount $>$ Ftable value, then $\mathrm{H} 0$ is rejected and $\mathrm{Ha}$ is accepted. Conversely, if the value of Fcount $<$ value of Ftable, then $\mathrm{H} 0$ is accepted and Ha is rejected. Simultaneous test results can be seen in Table 5 below

$\operatorname{ANOVA}^{b}$

\begin{tabular}{|c|c|c|c|c|c|}
\hline Model & Sum of Squares & Df & Mean Square & $\mathrm{F}$ & Sig. \\
\hline 1 Regression & 332070,142 & 3 & 110690,047 & 56,996 &, $000^{\mathrm{a}}$ \\
\hline Residual & 196149,233 & 101 & 1942,072 & & \\
\hline Total & 528219,376 & 104 & & & \\
\hline
\end{tabular}

a. Predictors: (Constant), DAK, PAD, DAU

b. Dependent Variable: Poverty_rate

The calculation obtained by the value of Fcount is 56.996. By using the $95 \%$ confidence interval or $=0.05$, the $\mathrm{F}$ distribution table obtained a value of 2.70 . By comparing the value of Fcount with Ftable, then Fcount (56.996) > Ftable (2.70). The decision is that $\mathrm{HO}$ is rejected and $\mathrm{Ha}$ is accepted, meaning that simultaneously the PAD, DAU, and DAK variables have a significant effect on the poverty rate in the province of Central Java.

Table 6. Results of Analysis of PAD, DAU and DAK on Poverty in DIY Coefficients $^{\text {a }}$

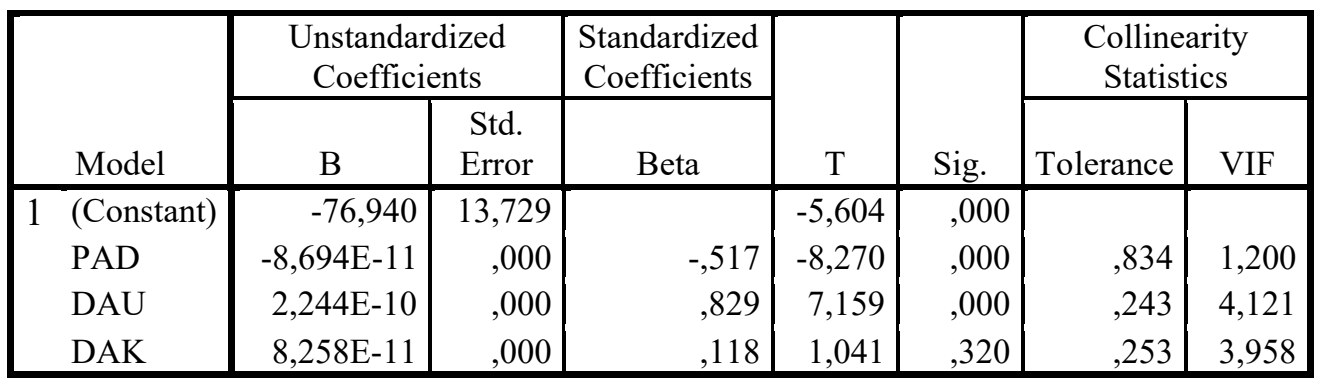

a. Dependent Variable: Poverty_rate 
Based on Table 6 using the $95 \%$ confidence interval or $=0.05$ The results of partial hypothesis testing show that the PAD variable has a tcount value (-8.270) > ttable value (2.18), then the decision is to accept $\mathrm{Ha}$ and $\mathrm{H} 0$ is rejected. This means that the PAD variable has a negative effect on the poverty rate in DIY. The two results of partial hypothesis testing show that the DAU variable has a tcount value (7.159) > ttable value (2.18), so the decision is to accept $\mathrm{Ha}$ and $\mathrm{H} 0$ is rejected. This means that the DAU variable has a significant effect on the poverty rate in DIY, and the results of partial hypothesis testing indicate that the DAK variable has a value of tcount $(1,041)<$ ttable value $(1,99)$, so the decision is to reject $\mathrm{Ha}$ and $\mathrm{HO}$ is accepted. This means that the DAU variable has no effect on the poverty rate in DIY.

\section{Discussion}

\section{The Effect of PAD on Poverty Rates in West Java Province}

The results of research conducted using the $95 \%$ confidence interval or $=0.05$, that partially shows the PAD variable has a tcount value (2.545) $>$ ttable value (1.99), then the decision is to accept $\mathrm{Ha}$ and $\mathrm{H} 0$ is rejected. This means that the PAD variable has a significant effect on the poverty rate in the province of West Java. The results of the study are in line with research conducted by Jolianis (2016) which says that PAD has an effect on poverty in districts and cities of West Sumatra province, also consistent with research conducted by Saragih (2003) which states that an increase in Regional Original Income (PAD) will encourage economic growth area. The increase in Regional Original Income (PAD) will trigger and spur regional economic growth to be better than the previous regional economic growth. Regional Original Revenue (PAD) is the main source of regional income to finance regional budgets, because the ability or contribution of Regional Original Revenue to the APBD will be a benchmark for regional economic growth. This proves that the increase in local revenue has not been able to increase the economic growth of West Java Province as evidenced by the increasing imbalance between the increase in the original regional income and economic growth.

\section{The effect of the DAU on the Poverty Rate in West Java Province}

The results of research conducted using the $95 \%$ or $=0.05$ that partially shows the DAU variable has a tcount value (3.970) $>$ ttable value (1.99), then the decision is to accept $\mathrm{Ha}$ and $\mathrm{H} 0$ is rejected. This means that the DAU variable has a significant effect on the poverty rate in the province of West Java. The results of the study are in line with research conducted by Jolianis (2016), which says that DAU has an effect on poverty in districts and cities of West Sumatra province. General allocation funds are a type of transfer of funds between levels of government that are not tied to certain expenditure programs. This general allocation fund is intended to replace transfers in the form of subsidies for autonomous regions and presidential instructions. The purpose of this transfer is to close the fiscal gap and equal distribution of fiscal capacity between regions between regions. So that the general allocation fund for each region will not be the same size. Regions that have low regional original income will 
get high general allocation funds, and vice versa regions that have high regional original income will get low general allocation funds.

\section{The Effect of DAK on Poverty Rates in West Java Province}

The results of my research using the $95 \%$ confidence interval or $=0.05$ partially indicate that the DAK variable has a tcount value $(5.468)>$ thable value (1.99), then the decision is to accept $\mathrm{Ha}$ and $\mathrm{H} 0$ is rejected. This means that the DAU variable has a significant effect on the poverty rate in the province of West Java. The results of the study are in line with research conducted by Kadafi and Murtala (2020) which said that DAK had an effect on poverty in East Java province. The results of this study are relevant to Government Regulation Number 104 of 2000, which clearly states the purpose of the use of DAK, as a result there is no clear direction in its use for both national priority projects and regional projects. Economic growth is also related to an increase in "output per capita". In this sense the theory must include a theory of GDP growth and a theory of population growth. Because only if these two aspects are explained, can the development of output per capita be explained. Then the third aspect is economic growth in the long-term perspective, that is, if over a long period of time the output per capita shows an increasing trend.

The effect of PAD, DAU and DAK on Poverty Rates in West Java Province

The results of the research I did using the $95 \%$ confidence interval or $=0.05$, the $\mathrm{F}$ distribution table obtained a value of 2.72. By comparing the value of Fcount with Ftable, then Fcount (67.897) > Ftable (2.72). The decision is that $\mathrm{H} 0$ is rejected and $\mathrm{Ha}$ is accepted, meaning that simultaneously the PAD, DAU, and DAK variables have a significant effect on the poverty rate in the province of West Java. The results of the study are in line with research conducted by Anwar et al (2016) which said that DAU, DAK and PAD had an effect on economic growth and poverty in Manado City in 2001 - 2013. Sustainable problems that have a close relationship in economic development are poverty and growth The economy is a picture of the development process. Development is a multidimensional process that involves major changes in social structures, mental attitudes and national institutions, including patterns of acceleration or acceleration of economic growth and absolute poverty eradication.

The Effect of PAD, DAU and DAK on Poverty Rates in Central Java Province

The results of my research using the $95 \%$ confidence interval or $=0.05$, partially show that the PAD variable has a tcount value (2.298) $>$ ttable value (1.99), then the decision is to accept $\mathrm{Ha}$ and $\mathrm{H} 0$ is rejected. This means that the PAD variable has a negative effect on the poverty rate in the province of Central Java. The results of the study are in line with research conducted by Jolianis (2016) which says that PAD affects poverty in districts and cities of West Sumatra province, also consistent with research conducted by Saragih (2003) which states that an increase in Regional Original Income (PAD) will encourage economic growth area. The increase in 
Regional Original Income (PAD) will trigger and spur regional economic growth to be better than the previous regional economic growth. Regional Original Revenue (PAD) is the main source of regional income to finance regional budgets, because the ability or contribution of Regional Original Revenue to the APBD will be a benchmark for regional economic growth. Supposedly an increase in regional original income will increase economic growth but empirically the findings of this study prove that an increase in regional original income has not been able to increase economic growth in Central Java Province as evidenced by an increasing imbalance between the increase in regional original income and economic growth.

The results of the research that I did using the $95 \%$ confidence interval or $=$ 0.05 , that partially shows the DAU variable has a tcount value $(6.704)>$ ttable value (1.99), then the decision is to accept $\mathrm{Ha}$ and $\mathrm{H} 0$ rejected. This means that the DAU variable has a significant effect on the poverty rate in the province of Central Java. The results of the study are in line with research conducted by Jolianis (2016) which says that the DAU has an effect on poverty in the districts of the province of West Sumatra. General allocation fund is a type of transfer of funds between levels of government that is not tied to a specific expenditure program. This general allocation fund is intended to replace transfers in the form of subsidies for autonomous regions and presidential instructions. The purpose of this transfer is to close the fiscal gap and equal distribution of fiscal capacity between regions between regions. So that the general allocation fund for each region will not be the same size. Regions that have low regional original income will get high general allocation funds, and vice versa regions that have high regional original income will get low general allocation funds.

The results of the research I did using the $95 \%$ confidence interval or $=0.05$ that partially shows the DAK variable has a tcount value (2.157) $>$ ttable value (1.99), then the decision is to accept $\mathrm{Ha}$ and $\mathrm{H} 0$ is rejected. This means that the DAU variable has a significant effect on the poverty rate in the province of Central Java. The results of the study are in line with research conducted by Ardiani Maulidia Octavia, Aris Soelistyo, Zainal Arifin 2018, which said that DAK had an effect on poverty in East Java province. The results of this study are relevant to Government Regulation No. 104 of 2000 , which clearly states the purpose of using DAK, as a result there is no clear direction in its use for both national priority projects and regional projects. Economic growth is also related to an increase in "output per capita". In this sense the theory must include a theory of GDP growth and a theory of population growth. Because only if these two aspects are explained, can the development of output per capita be explained. Then the third aspect is economic growth in the long-term perspective, that is, if over a long period of time the output per capita shows an increasing trend.

The results of the research that I did using the $95 \%$ confidence interval or $=0.05$ then the $\mathrm{F}$ distribution table obtained a value of 2.70 . By comparing the value of Fcount with Ftable, then Fcount (56.996) > Ftable (2.70). The decision is that H0 is rejected and $\mathrm{Ha}$ is accepted, meaning that simultaneously the PAD, DAU, and DAK 
variables have a significant effect on the poverty rate in the province of Central Java. The results of the study are in line with research conducted by Anwar et al (2016) which states that DAU, DAK and PAD have an effect on economic growth and poverty in Manado City in 2001 - 2013. Sustainable problems that are closely related to economic development are poverty and economic growth. is a description of the development process. Development is a multidimensional process that involves major changes in social structures, mental attitudes and national institutions, including patterns of acceleration or acceleration of economic growth and absolute poverty eradication.

\section{The effect of PAD, DAU and DAK on Poverty Rates in the Special Region of Yogyakarta}

The results of my research using the $95 \%$ confidence interval or $=0.05$, that partially shows the PAD variable has a tcount $(-8.270)>$ value $t$ table $(2,18)$, then the decision is to accept $\mathrm{Ha}$ and $\mathrm{HO}$ is rejected. This means that the PAD variable has a negative effect on the poverty rate in DIY. The results of the study are in line with research conducted by Jolianis (2016), which says that PAD affects poverty in districts and cities of West Sumatra province, also consistent with research conducted by Saragih (2003) which states that an increase in Regional Original Income (PAD) will encourage economic growth area. The increase in Regional Original Income (PAD) will trigger and spur regional economic growth to be better than the previous regional economic growth. Regional Original Revenue (PAD) is the main source of regional income to finance regional budgets, because the ability or contribution of Regional Original Revenue to the APBD will be a benchmark for regional economic growth. Supposedly an increase in regional original income will increase economic growth but empirically the findings of this study prove that an increase in regional original income has not been able to increase the economic growth of the DIY Province as evidenced by an increasing imbalance between the increase in regional original income and economic growth.

The results of the research that I did using the $95 \%$ confidence interval or $=$ 0.05 , that partially shows that the DAU variable has a tcount value $(7.159)>$ ttable value (2.18), then the decision is to accept $\mathrm{Ha}$ and $\mathrm{H} 0$ is rejected. This means that the DAU variable has a significant effect on the poverty rate in DIY. The results of the study are in line with research conducted by Jolianis (2016) which said that the DAU had an effect on poverty in the districts of the province of West Sumatra. General allocation fund is a type of transfer of funds between levels of government that is not tied to a specific expenditure program. This general allocation fund is intended to replace transfers in the form of subsidies for autonomous regions and presidential instructions. The purpose of this transfer is to close the fiscal gap and equal distribution of fiscal capacity between regions between regions. So that the general allocation fund for each region will not be the same size. Regions that have low regional original 
income will get high general allocation funds, and vice versa regions that have high regional original income will get low general allocation funds.

The results of the research I did using the $95 \%$ confidence interval or $=0.05$, that the partial hypothesis testing showed that the DAK variable had a tcount value $(1.041)<$ ttable value (1.99), so the decision was to reject $\mathrm{Ha}$ and $\mathrm{H} 0$ are accepted. This means that the DAK variable has no effect on the poverty rate in DIY. The findings of this study prove that DAK has no significant effect on poverty. This means that the higher the DAK received by the local government, it cannot reduce the number of poor people in the Regency/City in the DIY Province. The purpose of using DAK can be directed at efforts to improve the Human Development Index Opinion or Human Development Index, which is one of the national issues that needs to be resolved. From the results of this study, it can be said that the higher the DAK proposed by the local government for the poverty alleviation program has not been able to reduce the number of poor people in the DIY Province. So that in the future it is hoped that local governments will always propose more poverty alleviation programs to the central government through special allocation funds.

The results of the research that I did using the $95 \%$ confidence interval or $=0.05$ then the $\mathrm{F}$ distribution table obtained a value of 2.70. By comparing the value of Fcount with Ftable, then Fcount (98.787) > Ftable (3.59). The decision is that H0 is rejected and $\mathrm{Ha}$ is accepted, meaning that simultaneously the PAD, DAU, and DAK variables have a significant effect on the poverty rate in DIY. The results of the study are in line with research conducted by Meilita et al 2018, which said that DAU, DAK and PAD had an effect on economic growth and poverty in Manado City in 2001 2013. Sustainable problems that have close links in economic development, namely poverty and economic growth are: overview of the development process. Development is a multidimensional process that involves major changes in social structures, mental attitudes and national institutions, including patterns of acceleration or acceleration of economic growth and absolute poverty eradication.

The effect of PAD, DAU and DAK on Poverty Rates in East Java Province

The results of my research using the $95 \%$ confidence interval or $=0.05$, that partial hypothesis testing shows that PAD variable has a tcount $(-1.060)>$ ttable value (1.99), then the decision is to reject $\mathrm{Ha}$ and $\mathrm{HO}$ is accepted. This means that the PAD variable has no effect on the poverty rate in East Java Province. The results of the study are in line with research conducted by Dewi Chrisanty Paat et al 2018, which said that PAD had no effect on economic growth and its impact on poverty in Bitung City. These results are in line with research conducted by Prakarsa (2014) that Regional Original Income has an insignificant and negative impact on economic growth in East Java. Withdrawal of regional taxes and levies by local governments actually hampers regional economic growth. The government continues to strive to further improve the welfare of the community by continuing and further maximizing poverty alleviation efforts in Bitung City through various programs implemented by 
the Regional Poverty Reduction Coordination Team (TKPKD) and SKPD in East Java Province, namely various empowerment activities for small and medium enterprises and cooperatives, development and strengthening of farmer groups, increasing skills and capacity of the workforce, increasing production competitiveness as well as improving and developing agricultural infrastructure, policies for revitalizing agriculture, plantations and forestry.

The results of the research I did using the $95 \%$ confidence interval or $=0.05$, that partial hypothesis testing showed the DAU variable had a tcount value (7.397) > ttable value (1.99), then the decision was to accept $\mathrm{Ha}$ and $\mathrm{H} 0$ is rejected. This means that the DAU variable has a significant effect on the poverty rate in East Java Province. The results of the study are in line with research conducted by Jolianis (2016) which says that the DAU has an effect on poverty in the districts of the province of West Sumatra. General allocation fund is a type of transfer of funds between levels of government that is not tied to a specific expenditure program. This general allocation fund is intended to replace transfers in the form of subsidies for autonomous regions and presidential instructions. The purpose of this transfer is to close the fiscal gap and equal distribution of fiscal capacity between regions between regions. So that the general allocation fund for each region will not be the same size. Regions that have low regional original income will get high general allocation funds, and vice versa regions that have high regional original income will get low general allocation funds.

The results of the research that I did using the 95\% confidence interval or $=$ 0.05 , that the partial hypothesis testing showed that the DAK variable had a tcount value $(0.393)<$ ttable value $(1.99)$, then the decision was to reject $\mathrm{Ha}$ and $\mathrm{H} 0$ are accepted. This means that the DAK variable has no effect on the poverty rate in East Java Province. The findings of this study prove that DAK has no significant effect on poverty. This means that the higher the DAK received by the local government, it cannot reduce the number of poor people in the Regency/City in the DIY Province. Aswadi and Halim (2010) stated that the purpose of using DAK can be directed at efforts to improve the Human Development Index Opinion or Human Development Index, which is one of the national issues that needs to be resolved. From the results of this study, it can be said that the higher the DAK proposed by the local government for poverty alleviation programs has not been able to reduce the number of poor people in the DIY Province. through a special allocation fund.

The results of the research that I did using the $95 \%$ confidence interval or $=0.05$ then the $\mathrm{F}$ distribution table obtained a value of 2.70 . By comparing the value of Fcount with Ftable, then Fcount (62.753) > Ftable (2.70). The decision is that $\mathrm{H0}$ is rejected and $\mathrm{Ha}$ is accepted, meaning that simultaneously the PAD, DAU, and DAK variables have a significant effect on the poverty rate in East Java Province. The results of the study are in line with research conducted by Meilita et al 2018, which said that DAU, DAK and PAD had an effect on economic growth and poverty in Manado City in 2001 - 2013. Sustainable problems that have close links in economic development, 
namely poverty and economic growth are: overview of the development process. Development is a multidimensional process that involves major changes in social structures, accustomed mental attitudes and national institutions, including patterns of acceleration or acceleration of economic growth and absolute poverty eradication.

\section{CONCLUSION}

Based on the results of calculations using the SPSS method, it can be concluded that the province of West Java in PAD, DAU and DAK partially affect the poverty rate and PAD, DAU and DAK simultaneously affect the poverty rate. Central Java Province on PAD has a negative effect on poverty rates, DAU and DAK have a partial effect on poverty rates and PAD, DAU and DAK have a simultaneous effect on poverty rates. DIY Province, although PAD has a negative effect on poverty rates, DAU has an effect on poverty and DAK does not partially affect poverty rates and PAD, DAU and DAK have a simultaneous effect on poverty rates. East Java Province, Partially PAD has no effect on poverty rates, DAU has no effect on poverty rates and DAK has no effect on poverty rates and the influence of PAD, DAU and DAK simultaneously affects poverty rates.

For this reason, the government as the power user of the budget as well as the decision maker needs to carefully examine the allocation of the budget to be issued so that it can boost the existing economic growth, with the growth of the economy, the existing economic sectors will stretch and slowly develop which will open more many jobs, opening up investment which will ultimately provide income for the community so that the existing poverty level can be reduced. The Provincial Governments of West Java, Central Java, DIY and East Java must continue to increase their regional revenues, especially revenues sourced from Regional Original Revenue and the State Revenue and Expenditure Budget by seeking all potential sources of income in the Regency/City in each Province. The Provincial Governments of West Java, Central Java, DIY and East Java must strive to create investments that are conducive to regional economic growth and open up opportunities for workers so that the poverty rate does not increase.

\section{REFERENCES}

[1] Anwar, M.L., Palar, S.W \& Sumual, J. I. (2016). Pengaruh DAU, DAK, PAD Terhadap Pertumbuhan Ekonomi dan Kemiskinan di Kota Mando Tahun 2001-2013. Jurnal Berkala Ilmiah Efisiensi, 16(2), 218-232.

[2] Arini., Mustika \& Setyadhi, M. D. (2015). Pengaruh Pendapatan Asli Daerah dan Belanja Tidak Langsung terhadap Kemiskinan Melalui Pertumbuhan Ekonomi di Provinsi Bali Tahun 2007-2013. E-Jurnal Ekonomi Pembangunan, 4(9), 1140-1163.

[3] Davey, K. J. (1988). Pembiayaan Pemerintah Daerah: Praktek Praktek Internasional dan Relevansinya Bagi Dunia Ketiga. Jakarta: UI Press.

[4] Halim, A \& Nasir, J. A. (2006). Kanjian tentang Keuangan Daerah Pemerintah Malang (N. 06/Tahun XXXV, Ed.). Majalah Manajemen Usahawan Indonesia.

[5] Halim, A. (2010). Manajemen Keuangan Daerah. Yogyakarta: UPP-AMP YKPN. 
[6] Halim, A. (2014). Manajemen Keuangan Sektor Publik problematika penerimaan dan pengeluaran pemerintah. Jakarta: Salemba Empat.

[7] Jolianis. (2016). Analisis Pengaruh Pada PAD, DAU dan DAK terhadap Kemiskinan Pada Kabupaten/ Kota Di Propinsi Sumatera Barat dengan Pertumbuhan Ekonomi Sebagai Variabel Intervening. Journal of Economic and Economic Educatio, 4(2), 192 209. https://doi.org/10.22202/economica.2016.v4.i2.633

[8] Kadafi, M. \& M. (2020). Pengaruh Pendapatan Asli Daerah, Dana Alokasi Umum dan Dana Otonomi Khusus tehadap Tingkat Kemiskinan di Provinsi Aceh Periode 2010-2017.

Jurnal Ekonomi Regional Unimal, 3(2), 23-31.

[9] Kemenkes. (2020). Kementerian Keuangan. Retrieved from djpk.kemenkeu.go.id/

[10] Kuncoro, M. (2004). Otonomi \& Pembangunan Daerah, Reformasi, Perencanaan, Strategi, dan Peluang. Jakarta: Erlangga.

[11] Mahmudi. (2015). Manajemen Kinerja Sektor Publik. Jakarta: STIE YKPN.

[12] Mardiasmo. (2002). Otonomi dan Manajemen Keuangan Daerah (Bahasa Ind). Yogyakarta: Andi.

[13] Prakarsa, F.D \& Noor, I. (2014). Analisis Pengaruh Pendapatan Asli Daerah dan Pengeluaran Pemerintah Daerah terhadap Pertumbuhan Ekonomi (Studi Kasus di Kabupaten Kota Jawa Timur Tahun 2008-2012 (Vol. 2). Universitas Brawijaya.

[14] Sanit, A. (2011). Sistem Politik Indonesia, Kestabilan, Peta Kekuatan Politik dan Pembangunan. Jakarta: Rajawali Pers.

[15] Saragih, J. P. (2003). Desentralisasi Fiskal dan Keuangan Daerah dalam Otonomi. Bogor. Ghalia Indonesia.

[16] Sukarna, W. (2013). Keuangan Daerah dan Pelayanan Publik. Yogyakarta: P3DI Setjen DPR Republik Indonesia dan Azza Grafika.

[17] Suparmoko, M. (2002). Ekonomi Publik untuk Keuangan dan Pembangunan Daerah (1st ed.). Yogyakarta: Andi Yogyakarta.

[18] Suparmoko, M. (2010). Ekonomi Sumber Daya Alam dan Lingkungan. Yogyakarta: BPFE. 